\section{Kidney \\ Blood Pressure \\ Research}

\title{
To Treat or Not to Treat? Cost-Effectiveness of Ace Inhibitors in Non-Diabetic Advanced Renal Disease - a Dutch Perspective
}

\author{
Charles Christian Adarkwaha,b Afschin Gandjour ${ }^{\mathrm{c}} \quad$ Maren Akkerman $^{\mathrm{d}} \quad$ Silvia Evers $^{\mathrm{a}}$ \\ aCAPHRI School for Public Health and Primary Care, Department of Health Services Research, \\ Maastricht University, Maastricht, The Netherlands; ${ }^{b}$ Department of General Practice/Family Medicine, \\ Philipps University Marburg, Marburg, Germany; 'Frankfurt School of Finance and Management, \\ Frankfurt, Germany; dDepartment of Medicine III, RWTH-University Hospital Aachen, Aachen, Germany
}

\section{Key Words}

Advanced renal disease - Angiotensin-converting enzyme inhibitors - Cost-effectiveness • Decision modeling $•$ Markov model

\begin{abstract}
Background: Treating non-diabetic proteinuric patients with advanced renal disease with an angiotensin-converting enzyme (ACE) inhibitor is still subject to discussion. This study aims to determine the cost-effectiveness of ACE inhibitor therapy in this patient population in the Netherlands. Methods: We compared two strategies: first, treating patients with advanced renal disease with an ACE inhibitor and no-treatment. A lifetime Markov decision model was developed simulating the progression of renal disease and using published data on costs and health outcomes. A health care perspective was adopted. Results: In the base-case analysis, treatment with ACE inhibitors leads to higher benefits and lower costs and dominates the no-treatment strategy. Sensitivity analysis shows that the probability of savings is $83 \%$. Conclusion: ACE inhibitor treatment for non-diabetic patients with advanced renal disease in the Netherlands is highly cost-effective and should therefore be considered.
\end{abstract}

Copyright $\odot 2013$ S. Karger AG, Basel

\section{Introduction}

End stage renal disease (ESRD) can be defined by the need for renal transplantation or long-term dialysis [1]. It is a final outcome of advanced renal disease, which is defined as a serum creatinine $\geq 3.0 \mathrm{mg}$ per deciliter. An increasing prevalence of patients in renal replacement therapy in the Netherlands is notable within the last 15 years [2] as it almost 


\section{Kidney Blood Pressure Research}

doubled within this period. Currently, more than 15000 patients require renal-replacement therapy (RRT) and it is remarkable that the proportion of transplanted patients has been continuously increasing and now represents almost $60 \%$ of all patients requiring RRT [2].

ESRD costs represent a significant burden for the health care system, with a proportion of the national expenditures in European countries ranging from $0.7 \%$ in the UK to $1.8 \%$ in Belgium [3, 4], and with a proportion in the Netherlands of about $1.3 \%$. To state that prevention of ESRD is important from a medical perspective, it becomes clear that this also accounts for an economic viewpoint as the costs of ESRD treatment amount to €42 000 per patient per year in the Netherlands $[3,5,6]$.

Angiotensin-converting enzyme (ACE) inhibitors decelerate the progression from mildto-moderate chronic kidney disease (CKD, with a serum creatinine level of 1.5 to $3.0 \mathrm{mg}$ per deciliter) to ESRD in non-diabetic patients with hypertension [7-10]. ACE inhibitors have also shown to be cost-effective in this patient population. In the U. S., eg, benazepril treatment improves health and lowers costs as modelled over a 7-year period [11]. The costeffectiveness of ACE inhibitors in mild-to-moderate renal disease has also been shown for the Dutch setting $[3,12]$.

In patients with advanced renal disease (serum creatinine levels of $3.0 \mathrm{mg}$ per deciliter or more) physicians might be reluctant to use ACE inhibitors because of concern that potassium levels or serum creatinine will rise $[13,14]$. Several side effects and risks of ACE inhibitor therapy are well described in patients with chronic renal disease. Those risks include cough, hyperkalemia, mild reduction in glomerular filtration rate in patients with parenchymal renal disease, and acute renal failure in patients with bilateral renal artery stenosis or volume depletion [15-18]. A placebo-controlled randomized controlled trial (RCT) by Hou et al. [1] showed that ACE inhibitors can be used safely in this patient population: in the 8-week run-in period only 4 out of 281 patients with a serum creatinine above $3 \mathrm{mg} / \mathrm{ml}$ had to be excluded because of hyperkalemia; in the 224 patients who underwent randomization the incidence of hyperkalemia was similar among patients who received an ACE inhibitor and those who received placebo.

The RCT by Hou et al. [1] also showed that ACE inhibitor therapy has a renoprotective effect in this patient population, thus confirming the result of a small prior RCT [19]. Hou et al. demonstrated that the renal protective effect of ACE inhibitors in patients with advanced chronic kidney disease is not only due to their antihypertensive action as the reduction in the rate of progression changed little after correction for blood pressure [1]. Although more than $90 \%$ of patients in this study population suffered from hypertension (baseline blood pressure of $>150 / 85 \mathrm{~mm} \mathrm{Hg}$ ), these patients did not suffer from hypertensive kidney disease as the main cause for their renal failure. In about $60 \%$ glomerular disease was found to be the main cause [1].

A cost-effectiveness model conducted in Germany by Adarkwah et al. (2011) [20] suggests that ACE inhibitor treatment in this patient population is cost-effective, at least in the German setting. Currently, no data are available on the cost-effectiveness of ACE inhibitor therapy in non-diabetic patients with advanced nephropathy in the Dutch setting. However, results of the German study may not be transferable to the Netherlands. Different factors such as epidemiology of the disease, demography, the, availability of health care resources and differences in reimbursement systems between countries hinder transferability of economic evaluation studies between countries, in particularly due to variances in absolute and relative costs/prices. Other cost effectiveness models on renal disease even in the Dutch setting did include patients with less severe stages or renal disease, i.e. a serum creatinine level of 1.5 to $3.0 \mathrm{mg}$ per deciliter $[3,12]$. This also applies to other European cost-effectiveness models $[21,22]$. 


\section{Kidney Bloód Pressure Research}

Fig. 1. Schematic representation of the Markov decision models. ESRD $=$ end-stage renal disease.

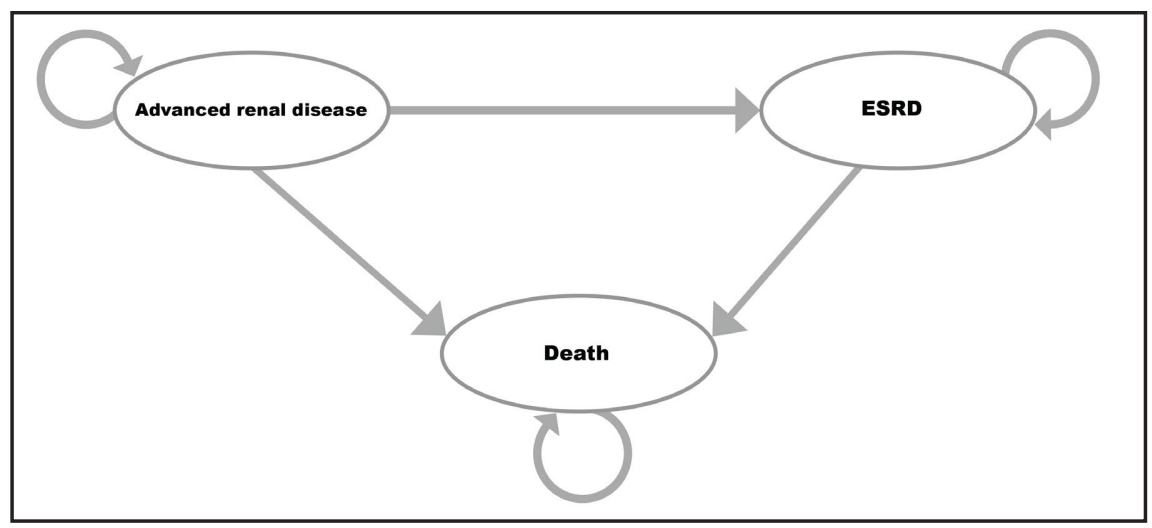

The goal of this paper was to determine the cost-effectiveness of ACE inhibitor therapy in non-diabetic patients with advanced renal disease (serum creatinine above $3.0 \mathrm{mg} / \mathrm{dl}$ ) and proteinuria in the Netherlands, based on a meta-analysis of RCTs by Ihle et al. [19] and Hou et al. [1].

\section{Materials and Methods}

\section{Overview and model design}

A Markov decision model previously developed for the German setting [20] was adapted and also proven suitable for the prevention of diabetic nephropathy $[23,24]$ in the Dutch and German setting.

Based on the results of the RCTs by Ihle et al. [19] and Hou et al. [1], the progression of a cohort of 1000 patients aged 44 years with advanced renal insufficiency (serum creatinine: $>3.0 \mathrm{mg} / \mathrm{dl}$, glomerular filtration rate (GFR): $15-26 \mathrm{ml} / \mathrm{min} / 1.73 \mathrm{~m}^{2}$ ), proteinuria, and hypertension (> 150/85 $\mathrm{mm} \mathrm{Hg}$ ), but without severe heart failure (New York Heart Association III or IV) was simulated.

In order to simulate costs and effectiveness over lifetime, a Markov model was constructed. A Markov model is an iterative process where patients stay in one cycle (ie, a defined health state) for a certain time (here: 1 year) and then make a transition to another cycle.

Markov models are useful when a decision problem involves risk that is continuous over time, when the timing of events is important, and when important events may happen more than once. A half-cycle correction was used to allow for transition events occurring midway through each 12-month cycle. A cycle length of one year was chosen because most data were given in units per year. The age of 100 was chosen as a cut-off as there are no mortality data available beyond this age. Regardless, more than $99 \%$ of patients in the simulation are dead at this age so that the model represents a lifetime horizon. The model was built in Microsoft Excel@ 2010.

Our model contains the following 3 health states (figure 1), which represent the occurrence of events after model entry:

1. Advanced renal disease (serum creatinine: $>3.0 \mathrm{mg} / \mathrm{dl}$, GFR: $15-26 \mathrm{ml} / \mathrm{min} / 1.73 \mathrm{~m}^{2}$, CKD stage 4)

2. ESRD and

3. Death

We performed a cost-utility analysis and health outcomes were measured in terms of quality-adjusted life years (QALYS). QALYs are the product of life years and a measure of health-related quality of life (preference weight or score) and allow comparing cost-effectiveness across diseases. Preference weights are anchored on a scale from 0 to 1, where 0 and 1 represent death and full health, respectively [25]. Economic outcomes were set in relation to clinical outcomes by dividing the incremental (ie, additional) costs of providing ACE inhibitors compared to no therapy by the incremental QALYs gained. The analysis is conducted from a health care perspective instead of choosing a societal perspective in order to increase comparability our previous model on this topic [20]. 


\section{Kidney Blood Pressure Research}

\begin{tabular}{|c|c|c|c|c|c|}
\hline \multirow{6}{*}{$\begin{array}{l}\text { Table } \mathbf{1} \text {. } \\
\text { Baseline char- } \\
\text { acteristics of } \\
\text { patients with } \\
\text { chronic kid- } \\
\text { ney disease }\end{array}$} & \multirow[t]{2}{*}{ Characteristics } & \multicolumn{2}{|c|}{ Hou et al. [1] } & \multicolumn{2}{|c|}{ Ihle et al. [19] } \\
\hline & & $\begin{array}{c}\text { ACE inhibitor } \\
(\mathrm{n}=112)\end{array}$ & $\begin{array}{l}\text { Placebo } \\
(\mathrm{n}=112)\end{array}$ & $\begin{array}{l}\text { ACE inhibitor } \\
\quad(\mathrm{n}=36)\end{array}$ & $\begin{array}{l}\text { Placebo } \\
(\mathrm{n}=34)\end{array}$ \\
\hline & Age - years & 44 & 45 & 41 & 48 \\
\hline & Male sex - no. (\%) & $56(50)$ & $55(49)$ & $23(64)$ & $13(38)$ \\
\hline & Blood pressure - mm Hg & & & & \\
\hline & Systolic & 153 & 152 & 147 & 154 \\
\hline & Diastolic & 87 & 85 & 87 & 88 \\
\hline & Renal function & & & & \\
\hline & Serum creatinine $-\mathrm{mg} / \mathrm{dl}$ & 4.0 & 3.9 & 5.2 & 4.4 \\
\hline & $\mathrm{GFR}-\mathrm{ml} / \mathrm{min} / 1.73 \mathrm{~m}^{2}$ & 26.3 & 25.8 & 14.6 & 15.8 \\
\hline & Urine protein excretion - g/day & 1.6 & 1.7 & 2.3 & 1.9 \\
\hline
\end{tabular}

Doubling of the serum creatinine level (an outcome in the RCT by Hou [1]) was not included as a separate Markov state, as this is a surrogate for and shortly followed by ESRD. After each cycle, a specified proportion of patients move from advanced renal insufficiency to ESRD. This transition is delayed by ACE inhibitors. Simultaneously, a specified proportion of patients die. During each cycle, patients accumulate utilities (measured by QALYs) and costs.

Combining both states - dialysis and transplant - to ESRD is a common course of action when modelling renal disease [26, 27]. We pooled individual data for transplantation and dialysis as well as prevalences according to the national register in order to assess valid costs for the stage ESRD.

\section{Clinical strategies}

Two treatment strategies were considered. In the "ACE inhibitor treatment" strategy, patients are treated with benazepril $10 \mathrm{mg}$ twice a day. Patients in the control group receive no ACE inhibitor. In addition, both groups receive other antihypertensive agents (diuretics, alpha- or beta-blockers, calcium-channel antagonists, or some combination of these medications), but no other renin-angiotensin-system agents.

\section{Transition probabilities}

In order to identify placebo-controlled RCTs on the effect of ACE inhibitors on the progression of advanced renal insufficiency to ESRD we used a literature review until July 2001 by Terajima et al. [28] as a starting point. This paper found one placebo-controlled RCT [19]. In order to identify additional placebocontrolled RCTs published after July 2001 we searched in the PubMed database (date: September 05, 2012) using the following search strategy:

Renal Insufficiency, Chronic AND creatinine AND antihypertensives AND end-stage renal disease AND angiotensin-converting-enzyme NOT(type-2-diabetes), Limits: Randomized Controlled Trial, All Adult: $19+$ years.

We obtained 43 hits. Thereof, 41 papers were excluded because they did not compare ACE inhibitors to placebo, did not consider advanced renal insufficiency, or did not include ESRD as an outcome. The above mentioned REIN study $[9,10]$ including amongst other Dutch nephropathy patients was excluded because the overall patient population suffered from mild-to-moderate renal disease and therefore also did not meet our inclusion criteria. The only 2 studies left were by Ihle et al. [19] and Hou et al. [1] and therefore used as the source of our effectiveness data. Both studies $[7,8]$ were double-blinded (see table 1 for baseline characteristics). To combine effectiveness data from both studies and estimate the common odds ratio, we used the Mantel-Haenszel test [29].

In order to determine the annual transition probability from advanced renal disease to ESRD without ACE inhibitor therapy, we first calculated a total probability for each of the two trials, by dividing the number of events (ESRD) during the trial period in the control arm by the number of patients. Second, we determined the annual transition probability by assuming a constant annual hazard rate over the study time horizon [30]. And third, we determined a weighted average rate, with the number of individuals included in each study as weights. In the study by Hou et al. [1] the number of events was obtained by directly contacting the authors and does not include death. 


\section{Kidney Blood Pressure Research}

Table 2. Data used to determine the cost-effectiveness of angiotensin-converting enzyme inhibitor treatment

\begin{tabular}{|c|c|c|c|}
\hline Variable & Base-case estimate & Range* & References \\
\hline \multicolumn{4}{|l|}{ Annual transition probabilities } \\
\hline Advanced renal insufficiency to ESRD without ACE inhibitor & 0.14 & $0.08-0.19$ & {$[1,19]$} \\
\hline Advanced renal insufficiency to death & $\begin{array}{l}\text { Age- and gender } \\
\text { dependent }\end{array}$ & $0.003-0.54$ & [61] \\
\hline ESRD to death & 0.09 & --- & [2] \\
\hline \multicolumn{4}{|l|}{ Effectiveness of ACE inhibitor } \\
\hline \multicolumn{3}{|l|}{ Utilities (health states) } & {$[1,19]$} \\
\hline General population (age-dependent) & $0.83-0.94$ & --. & [33] \\
\hline Disutility of chronic kidney disease & 0.056 & $-0.045-0.156$ & [32] \\
\hline Disutility of ACE inhibitor treatment & 0.00 & $0.00-0.05$ & [34] \\
\hline ESRD & 0.62 & $0.39-0.84$ & [35] \\
\hline \multicolumn{4}{|l|}{ Annual costs, $€$} \\
\hline General health care expenditures by age group & $3.140,58-23.456,58$ & --- & {$[39,42,47]$} \\
\hline $\begin{array}{l}\text { Per-patient cost of chronic kidney disease compared to non- } \\
\text { CKD population }\end{array}$ & Age-dependent & --- & {$[39-36,42,47]$} \\
\hline $\begin{array}{l}\text { ACE inhibitor } \\
\text { ( } 20 \mathrm{mg} \text { benazepril daily; } 5 \mathrm{mg} \text { enalapril daily in the SA) }\end{array}$ & 240,92 & $28,70-240,92$ & [43] \\
\hline ESRD & 42110 & $33688-50532$ & {$[2,6]$} \\
\hline Transplantation & 14387 & & {$[2,6]$} \\
\hline Dialysis & 79122 & & {$[2,6]$} \\
\hline Home/in-center hemodialysis & 83217 & & {$[2,6]$} \\
\hline CAPD & 54067 & & {$[2,6]$} \\
\hline CCPD & 69546 & & {$[2,0]$} \\
\hline SMR of chronic kidney disease & 3.42 & $2.84-4.11$ & [31] \\
\hline Discount rate of costs & 0.04 & $0.00-0.10$ & {$[42,47,48]$} \\
\hline Discount rate of benefits & 0.015 & $0.00-0.10$ & {$[42,47,48]$} \\
\hline $\begin{array}{l}\text { ESRD = end-stage renal disease; } \mathrm{ACE}=\text { angiotensin-converti } \\
\text { analysis; CAPD = Continuous ambulatory peritoneal dialysis } \\
\text { standardized mortality ratio; }{ }^{*} \text { Tested in sensitivity analysis: } \\
\text { ESRD (estimate) }\end{array}$ & $\begin{array}{l}\text { zyme; } C K D=\text { chron } \\
D=\text { Continuous cyc } \\
d \text { on } 95 \% \text { confiden }\end{array}$ & $\begin{array}{l}\text { ney disease; SA } \\
\text { eritoneal dialys } \\
\text { ervals of the m }\end{array}$ & $\begin{array}{l}\text { Mnsitivity } \\
\text { except for }\end{array}$ \\
\hline
\end{tabular}

Transition probabilities with and without an ACE inhibitor therapy are shown in table 2. In patients without ESRD mortality was regarded as a function of age. Specifically, we used age-specific mortality rates of non-diabetic patients. To calculate the latter, age-specific mortality rates of the general population were multiplied with a standardized mortality ratio for patients with advanced renal disease compared to the general population, which was derived from a large community-based cohort study [31]. For patients with ESRD we assumed that mortality was age-independent.

\section{Preference weights}

For patients in the health state "advanced renal disease" we considered a utility loss according to a survey using the time tradeoff (TTO) method in 65 patients [32]. This population had a mean age of 66 years and a GFR between 15 and $30 \mathrm{ml} / \mathrm{min} / 1.73 \mathrm{~m}^{2}$. Furthermore, we considered an age-dependent loss of utility [33]. For patients treated with an ACE inhibitor a disutility of 0.05 from all side effects was considered in a sensitivity analysis [34]. The preference weight for ESRD was derived from a systematic review of empirical studies in which TTO weights were provided by patients [35]. The TTO can be regarded as the most commonly used method to derive quality-of-life weights for QALYs [36, 37]. The TTO technique determines the proportion of remaining life years in poor health which patients are willing to give up or trade in exchange for perfect health. Based on patient responses utility scores are calculated. Those utility measures in economic evaluations are becoming more and more important given the fact that decision makers are asked to optimize the allocation of scarce health care resources across disease areas and patient groups [38]. Notably, the values are similar to EQ-5D scores (baseline value 0.61) reported by de Wit et al. [6]. We tested a rather broad range of TTO weights in sensitivity analysis.

Costs

The analysis was conducted from the health care perspective. Therefore, only direct health effectsdefined as life years gained - and direct costs and were considered. Making use of data on the consumer 


\section{Kidney \\ Blood Pressure Research}

Kidney Blood Press Res 2013;37:168-180

\begin{tabular}{l|l}
\hline DOI: $10.1159 / 000350142$ & C 2013 S. Karger AG, Basel
\end{tabular}

www.karger.com/kbr

Adarkwah/Gandjour/Akkerman/Evers: ACE Inhibitors in Advanced Renal Disease
Table 3. Parameters used for calculating the cost of end-stage renal disease (see cost section under "Methods")

\begin{tabular}{cc}
\hline variable & meaning \\
\hline 1 & CAPD $^{*}$ \\
2 & CCPD $^{* *}$ \\
3 & 0.82 \\
$\beta_{1}$ & 0.106 \\
$\beta_{2}$ & 0.074 \\
$\beta_{3}$ & $€ 83217$ \\
$x_{1}$ & $€ 54067$ \\
$x_{2}$ & $€ 69546$ \\
$x_{3}$ & 0.43 \\
$\mathrm{p}$ & $€ 79112$ \\
$\mathrm{X}$ & $€ 14387$ \\
$\mathrm{Y}$ & \\
\hline$*$ continuous ambulatory peritoneal dialysis; \\
$*$ continuous cycling peritoneal dialysis \\
\hline
\end{tabular}

price index, costs were inflated to year 2010 euros [39]. Costs of health care expenditures unrelated and related to CKD as well as costs for ACE inhibitors and treatment of ESRD were accounted for. To determine the health care expenditures related and unrelated to CKD, we took resource consumption into account, based on international guidelines for the treatment of CKD $[40,41]$. The recommendations of the Dutch guidelines for pharmacoeconomic research were followed [42].

In the base case, the cheapest generic of benazepril $10 \mathrm{mg}$ daily was used twice daily [43]. We included costs of ACE inhibitor therapy for patients who had to be excluded in the 8-week run-in period as these patients would be treated in the real world. In a sensitivity analysis we applied the price of the cheapest generic of enalapril $5 \mathrm{mg}$ once daily as used in the RCT by Ihle et al. [19]. This is, for instance, the most frequently prescribed ACE inhibitor in the Netherlands [44].The costs of benazepril and enalapril were based on 2010 Dutch prices and include 6\% value-added tax as well as a 3-monthly pharmacists' prescription fee of €7.50 [45].

The annual costs of patients with ESRD were calculated as a weighted average of the costs of renal transplantation as well as different types of dialysis as based on a Dutch study [6] and prevalence data available from the national register [2].

In detail, the following calculations were made (see table 3 in the appendix for details):

1) cost of dialysis $=\beta_{1} x_{1}+\beta_{2} X_{2}+\beta_{3} X_{3}=\mathrm{X}$, where $x_{\mathrm{n}}=$ annual cost of dialysis treatment $n=1,2,3 ; \beta_{\mathrm{n}}=$ prevalence weight of the dialysis treatment, and $\beta_{1}+\beta_{2}+\beta_{3}=1$

2) cost of ESRD $=p \mathrm{X}+(1-p) \mathrm{Y}$, where $\mathrm{Y}=$ cost of renal transplantation and $p=$ proportion of ESRD treated by dialysis treatment.

We assumed a transplant survival of 10 years and a distinction was made between the first year of transplantation and the years following [46]. Costs were inflated to 2010 Dutch prices.

As our study population is mainly hypertensive (91.5\%) and no valid data on CKD treatment costs per se are available, we included the costs for hypertension treatment as an approximation. Costs were discounted at an annual rate of $4 \%$ whereas benefits were discounted at an annual rate of $1.5 \%$ in accordance with the CVZ recommendations [42, 47, 48].

\section{Sensitivity analysis}

In order to address uncertainty around mean incremental costs and effectiveness, we conducted univariate sensitivity analyses, where we varied one variable at a time while keeping all other variables constant at their mean or base-case value. We ran analyses using the upper and lower bound of the $95 \%$ confidence intervals of the mean whenever possible. For transplantation costs we did not have information on the $95 \%$ CI and thus varied costs by $20 \%$ (see table 2 for uncertainty ranges).

To assess how a simultaneous change of several variables affects the incremental cost-effectiveness ratio (ICER), we performed a Monte Carlo simulation, a type of multivariate sensitivity analysis. This method runs a large number of simulations (here: 1000) by repeatedly drawing samples from probability distributions of input variables. Therefore, it provides a probability distribution for the output variables (incremental costs, incremental effectiveness, and ICERs). Cost data were assumed to follow a gamma distribution Gamma(a, b), which reflects the long right tail and restriction to positive values. Probabilities 


\section{Kidney Blood Pressure Research}

Table 4. Results of the base-case analysis, based on mean estimates of input variables

\begin{tabular}{lcccc}
\hline Strategy & Costs $(€)$ & Undiscounted LYs & Discounted QALYs & ICER (€/QALY) \\
\hline No ACE inhibitor treatment & 220942 & 13.38 & 9.32 & Dominates \\
ACE inhibitor treatment & 183535 & 14.66 & 11.11 & \\
\hline ACE = angiotensin-converting enzyme; LYs = life-years; QALY = quality-adjusted life-years; ICER = incremental \\
cost-effectiveness ratio
\end{tabular}

were assumed to follow a beta distribution $\operatorname{Beta}(\alpha, \beta)$ because they are normally distributed but restricted to take on values between 0 and 1 . The standard error of a probability or proportion was calculated according to the following formula [49]:

$$
\sigma=\sqrt{\frac{p(1-p)}{n}}
$$

Where $p=$ probability and $n=$ sample size. Relative risks and odds ratios were assumed to follow a lognormal distribution.

Based on the Monte-Carlo simulation we generated a cost-effectiveness acceptability curve (CEAC). A CEAC allows a decision-maker to consider whether a prevention strategy is cost-effective in relation to the maximum amount a decision-maker is willing to pay for a QALY. At each ceiling value for the willingness to pay for a QALY, the cost-effectiveness acceptability curve shows the probability that the treatment is costeffective.

\section{Results}

Base case

The base-case analysis, which had a lifetime horizon, shows domination of the ACE inhibitor treatment strategy over the no treatment strategy (table 4). Treatment was therefore associated with lower costs and larger health benefit. Even shorter-term simulations over 3 and 10 years revealed the same finding, ie, lower costs and larger benefits.

\section{Sensitivity analysis}

Variables with the largest impact on incremental costs and effectiveness in the univariate sensitivity analysis are the effectiveness of ACE inhibitor treatment, the costs of ESRD, and the discount rates of costs and effects (table 5). Figure 2 shows the cost-effectiveness acceptability curve, considerung uncertainty in cost-effectiveness. Replications with lower effectiveness of the "ACE inhibitor treatment" strategy compared to the "no treatment" strategy $(1.6 \%)$ were categorized as not cost-effective (regardless of concurrent savings). This is because it would be unethical to accept treatment that is less effective than no treatment. Hence, the maximum probability of cost-effectiveness independent of the willingness to pay is $98.4 \%$. The probability of savings is $83 \%$. A scatter plot is presented in figure 3 .

\section{Discussion}

The study shows that treating non-diabetic patients with advanced renal insufficiency in the Netherlands with ACE inhibitors saves both money and lives. Despite the considerable costs of dialysis treatment, preventing ESRD does not necessarily lead to savings [50], thus necessitating a detailed calculation of costs and benefits. This result is consistent with a previous cost-effectiveness analysis conducted in the German setting [20]. Treating patients with more advanced renal disease (creatinine $\geq 3.0 \mathrm{mg}$ per deciliter) with an ACE inhibitor to delay disease progression is still subject to discussion and no clear guideline statement regarding this aspect is available to date [51-53]. Therefore results could be helpful to adjust current guideline recommendations. 


\section{Kidney Bloód Pressure Research}

Table 5. Univariate sensitivity analyses from a health care perspective: effects of varying base-case estimates on the incremental cost-effectiveness ratio of treating all patients with advanced renal insufficiency with an ACE inhibitor vs no ACE inhibitor treatment (reference strategy). "Lower bound" and "higher bound" refer to the limits of the $95 \%$ confidence interval or estimate thereof

\begin{tabular}{|c|c|c|c|c|c|c|}
\hline & Lowe & bound & ICER & Highe & bound & ICER \\
\hline & $\begin{array}{c}\text { Incremental } \\
\text { costs }\end{array}$ & $\begin{array}{c}\text { Incremental } \\
\text { QALYs }\end{array}$ & & $\begin{array}{c}\text { Incremental } \\
\text { costs }\end{array}$ & $\begin{array}{c}\text { Incremental } \\
\text { QALYs }\end{array}$ & \\
\hline Annual transition probabilities fro & advanced ren & I insufficiency & ESRD & & & \\
\hline Without ACE inhibitor & $-€ 36685$ & 1.76 & $\mathrm{D}$ & $-€ 32842$ & 1.62 & $\mathrm{D}$ \\
\hline Effectiveness of ACE inhibitor & & & & & & \\
\hline $\begin{array}{l}\text { Relative risk of advanced } \\
\text { renal insufficiency to ESRD }\end{array}$ & - €72 134 & 3.39 & $\mathrm{D}$ & $-€ 2673$ & 0.17 & $\mathrm{D}$ \\
\hline Utilities (health states) & & & & & & \\
\hline Chronic kidney disease & - €37 407 & 1.63 & $\mathrm{D}$ & $-€ 37407$ & 1.86 & $\mathrm{D}$ \\
\hline ESRD & - €37 407 & 2.01 & D & $-€ 37407$ & 1.58 & $\mathrm{D}$ \\
\hline $\begin{array}{l}\text { Disutility of ACE inhibitor } \\
\text { treatment }\end{array}$ & - €37 407 & 1.79 & D & $-€ 37407$ & 1.57 & D \\
\hline Costs & & & & & & \\
\hline ACE inhibitor & - €36 680 & 1.79 & $\mathrm{D}$ & - €37407 & 1.79 & $\mathrm{D}$ \\
\hline ESRD & $-€ 28400$ & 1.79 & $\mathrm{D}$ & $-€ 46415$ & 1.79 & $\mathrm{D}$ \\
\hline$S M R$ & $-€ 37307$ & 1.88 & $\mathrm{D}$ & $-€ 37521$ & 1.69 & $\mathrm{D}$ \\
\hline Base case & $-€ 37407$ & 1.79 & $\mathrm{D}$ & & & \\
\hline Discount rate of costs & & & & & & \\
\hline $0 \%$ & - €49072 & 1.79 & $\mathrm{D}$ & & & \\
\hline $5 \%$ & - €35 105 & 1.79 & $\mathrm{D}$ & & & \\
\hline $7 \%$ & $-€ 31066$ & 1.79 & $\mathrm{D}$ & & & \\
\hline $10 \%$ & - €26158 & 1.79 & $\mathrm{D}$ & & & \\
\hline Discount rate of effects & & & & & & \\
\hline $0 \%$ & - €37407 & 2.31 & D & & & \\
\hline $5 \%$ & $-€ 37407$ & 1.07 & D & & & \\
\hline $7 \%$ & - €37 407 & 0.84 & $\mathrm{D}$ & & & \\
\hline $10 \%$ & $-€ 37407$ & 0.60 & $\mathrm{D}$ & & & \\
\hline
\end{tabular}

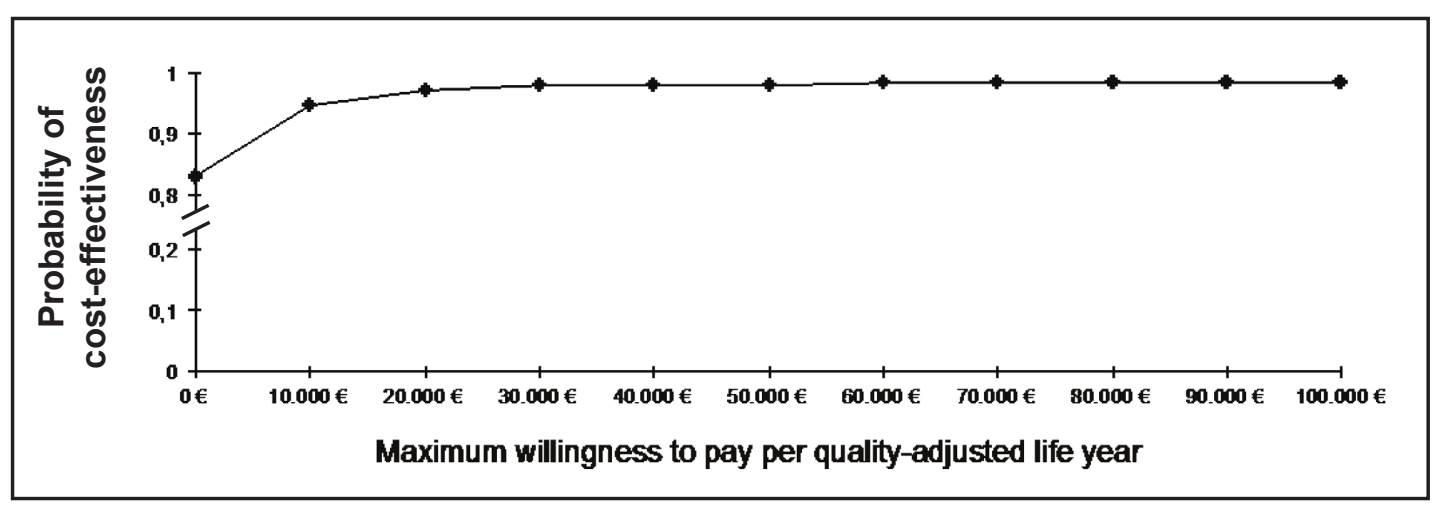

Fig. 2. Cost-effectiveness acceptability curve.

Still, our model is subject to some limitations. In modeling studies this is usually the case due to constraints of resources, time, and information availability. The cost-effectiveness by treating non-diabetic progressed chronic kidney disease with ACE inhibitors may be even underestimated for several reasons. First, we did not model that ACE inhibitors reduce the risk for cardiovascular events [54,55], which leads to additional savings. As our study does not consider savings from avoiding cardiovascular events, it does, however, consider that 


\section{Kidney Blood Pressure Research}

Fig. 3. Cost-effectiveness plane showing 1000 replications from a distribution of cost and quality-adjusted life year (QALY) differences (angiotensin-converting enzyme inhibitor vs no treatment).

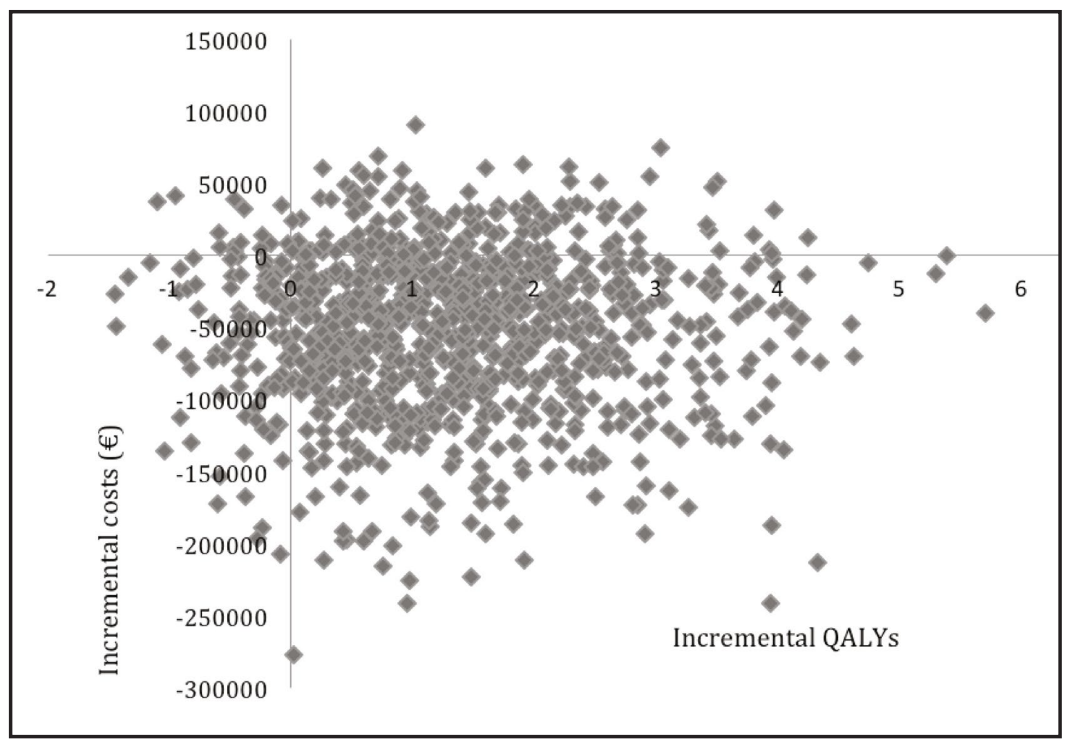

patients with chronic kidney disease have a higher risk of to die because of cardiovascular reasons. We captured this by the mortality ratio for patients with chronic kidney disease compared to the general population. Second, effectiveness (and thus savings) of benazepril may have been underestimated as ESRD treatment may have been initiated earlier than necessary in the ACE inhibitor arms of the RCTs by Hou et al. [1] and Ihle et al. [19] due to a drug-induced GFR decrease. Third, we did not consider on the cost side that some patients may discontinue ACE inhibitor therapy and therefore incur no drug costs. The reason is that information on compliance was unavailable in the two RCTs $[1,19]$. Treatment discontinuation was only considered on the effect side, as the rate of compliance is implicitly incorporated in clinical trial results, ie, efficacy data refer both to adherers and non-adherers. Therefore the Markov model includes patients who discontinue ACE inhibitor treatment in the ACE inhibitor arm. And forth, for patients who receive dialysis we were not able to consider health care costs unrelated to dialysis due to a lack of available data.

On the other hand, the savings might be smaller than estimated by our model. This is because some elderly patients may have a preference against replacement therapy and hence do not incur the associated costs. The bias seems small, however, given that the percentage of elderly patients requiring RRT is small (eg, less than $3 \%$ at the age of 80 years and above) according to the register. Further limitations of the model relate to its data sources.

First, the two trials considered as the source of our effectiveness data used for ACE inhibition enalapril and benazepril, respectively. Whether other types of ACE inhibitors can achieve the results reported in these studies is not clear. ACE inhibitors have potentially important differences in plasma protein binding, their affinity for ACE, and pharmacokinetics [56]. To date, there is no convincing evidence that generic long-acting ACE inhibitors (such as lisinopril and enalapril) are inferior to brand-name ACE inhibitors [56, 57].

Second, our preference weights for patients with advanced renal disease were taken from a U. S. study [32] as no similar data for Dutch patients were available.

Third, the model also uses some epidemiological data from Western countries other than the Netherlands. One of the two studies we used as the source of our effectiveness data [1] was conducted in China. There is a debate on whether a significant difference between white and Asian populations exists due to ACE gene polymorphism, which might lead to a difference in the efficacy of ACE inhibitors. In fact, studies examining the association between differences in ACE gene polymorphism and the efficacy of ACE inhibitors have had contradictory results [58]. In a controlled trial performed among Japanese patients with 


\section{Kidney \\ Blood Pressure Research}

non-diabetic chronic kidney disease whose blood pressure was maintained at an average of 126/72 mm Hg with ACE inhibitors, no significant correlation was observed between the type ACE gene polymorphism (DD, ID, or II) and the efficacy of the intervention or renal outcome [59]. On the other hand, a controlled trial among 212 whites showed that ACE inhibitor therapy was protective against progression to ESRD only in patients with the DD genotype [60]. But even if this small trial is confirmed, treating whites regardless of ACE genotype may not have a smaller impact than treating Asians as whites with the DD genotype may have a stronger response than the average Asian patient. Furthermore, the study by Ihle et al. [19], which was conducted in Australia, shows a similar result as the study by Hou et al. [1].

Forth, quality of life values were derived from non-Dutch populations due to a lack of availability. Hence, we tested a broad range of TTO values in sensitivity analysis.

And fifth, longitudinal studies that have examined long-term outcomes of ACE inhibitor treatment in patients with advanced chronic kidney disease are not available for model validation. This is a common limitation of models on the prevention of renal failure.

In addition, the costs of dialysis treatment will likely continue to rise in the future, and therefore increase the potential for savings by preventing ESRD. Dialysis costs have significantly increased within the last years [5].We expect this trend to continue due to stricter regulations concerning dialysis safety, better-tolerated dialysis solutions and technological advancement of dialysis machines. On the other hand, prices of erythropoietin and reimbursement of physicians may drop.

\section{Conclusion}

For patients with non-diabetic proteinuric advanced renal disease, treatment with an ACE inhibitor is highly cost-effective and should therefore be considered. A societal perspective will likely lead to even larger savings than a health care perspective as ACE inhibitor treatment avoids productivity loss due to renal failure. Yet, the transferability of the conclusion of this study to other countries is limited given differences in costs, clinical management (eg, treatment of ESRD), and epidemiology.

\section{Conflict of Interests}

There are no potential conflicts of interest.

\section{Acknowledgements}

No funding was received.

\section{References}

1 Hou FF, Zhang X, Zhang GH, Xie D, Chen PY, Zhang WR, Jiang JP, Liang M, Wang GB, Liu ZR, Geng RW: Efficacy and safety of benazepril for advanced chronic renal insufficiency. N Engl J Med 2006;354:131-140. Dutch End-Stage Renal Disease Registry (Registratie Nierfunktievervanging Nederland) 2011. Available: https://www.renine.nl/page?id=home\&lang=en. Accessed 18 October 2011.

- Vegter S, Perna A, Hiddema W, Ruggenenti P, Remuzzi G, Navis G, Postma MJ: Cost effectiveness of ACE inhibitor therapy to prevent dialysis in nondiabetic nephropathy: influence of the ACE insertion/deletion polymorphism. Pharmacogenet Genomics 2009;19:695-703.

-4 Peeters P, Rublee D, Just PM, Joseph A: Analysis and interpretation of cost data in dialysis: review of Western European literature. Health Policy 2000;54:209-227. 


\section{Kidney \\ Blood Pressure Research}

5 van Os N, Niessen LW, Bilo HJ, Casparie AF, van Hout BA: Diabetes nephropathy in the Netherlands: a cost effectiveness analysis of national clinical guidelines. Health Policy 2000;51:135-147.

6 de Wit GA, Ramsteijn PG, de Charro FT: Economic evaluation of end stage renal disease treatment. Health Policy 1998;44:215-232.

7 Maschio G, Alberti D, Janin G, Locatelli F, Mann JF, Motolese M, Ponticelli C, Ritz E, Zucchelli P: Effect of the angiotensin-converting-enzyme inhibitor benazepril on the progression of chronic renal insufficiency. $\mathrm{N}$ Engl J Med 1996;334:939-945.

8 Ruggenenti P, Perna A, Benini R, Remuzzi G: Effects of dihydropyridine calcium channel blockers, angiotensin-converting enzyme inhibition, and blood pressure control on chronic, nondiabetic nephropathies. J Am Soc Nephrol 1998;9:2096-2101.

-9 The GISEN Group: Randomised placebo-controlled trial of effect of ramipril on decline in glomerular filtration rate and risk of terminal renal failure in proteinuric, non-diabetic nephropathy. Lancet 1997;349:1857-1863.

10 Gruppo Italiano di Studi Epidemiologici in Nefrologia (GISEN): A long-term, randomised clinical trial to evaluate the effects of ramipril on the evolution of renal function in chronic nephropathies. J Nephrol 1991;3:193-202.

11 Hogan TJ, Elliott WJ, Seto AH, Bakris GL: Antihypertensive treatment with and without benazepril in patients with chronic renal insufficiency: a US economic evaluation. Pharmacoeconomics 2002;20:37-47.

12 van Hout BA, Simeon GP, McDonnell J, Mann JF: Economic evaluation of benazepril in chronic renal insufficiency. Kidney Int 1997;63:S159-S162.

13 Bakris GL, Weir MR: Angiotensin-converting enzyme inhibitor-associated elevations in serum creatinine: is this a cause for concern? Arch Intern Med 2000;160:685-693.

14 Moser M: Angiotensin-converting enzyme inhibitors, angiotensin II receptor antagonists and calcium channel blocking agents: a review of potential benefits and possible adverse reactions. J Am Coll Cardiol 1997;29:1414-1421.

15 Brunner HR: ACE inhibitors in renal disease [Clinical Conference]. Kidney Int 1992;42:463-479.

-16 Israili ZH, Hall WD: Cough and angioneurotic edema associated with angiotensin-converting enzyme inhibitor therapy. A review of the literature and pathophysiology. Ann Intern Med 1992;11:234-242.

17 Keane FW. Anderson S. Aurell M, de Zeeuw D, Narins RG, Povar G: Angiotensin converting enzyme inhibitors and progressive renal insufficiency. Current experience and future directions. Ann Intern Med 1989;111:503-516.

18 Brown NJ, Vaughan DE: Angiotensin-converting enzyme inhibitors. Circulation 1998;14:1411-1420.

19 Ihle BU, Whitworth JA, Shahinfar S, Cnaan A, Kincaid-Smith PS, Becker GJ: Angiotensin-converting enzyme inhibition in nondiabetic progressive renal insufficiency: a controlled double-blind trial. Am J Kidney Dis 1996;27:489-495.

20 Adarkwah CC, Gandjour A: Cost-effectiveness of angiotensin-converting enzyme inhibitors in non-diabetic advanced renal disease. Expert Rev Pharmacoecon Outcomes Res 2011;11:215-223.

-21 Ruggenenti P, Pagano E, Tammuzzo L, Benini R, Garattini L, Remuzzi G: Ramipril prolongs life and is cost effective in chronic proteinuric nephropathies. Kidney Int 2001;59:286-294.

-22 Schädlich PK, Brecht JG, Brunetti M, Pagano E, Rangoonwala B, Huppertz E: Cost effectiveness of ramipril in patients with non-diabetic nephropathy and hypertension: economic evaluation of Ramipril Efficacy in Nephropathy (REIN) Study for Germany from the perspective of statutory health insurance. Pharmacoeconomics 2001;19:497-512.

23 Adarkwah CC, Gandjour A: Cost-effectiveness of angiotensin-converting enzyme inhibitors and angiotensin II receptor blockers in newly diagnosed type 2 diabetes in Germany. Int J Technol Assess Health Care 2010;26:62-70.

24 Adarkwah CC, Gandjour A, Akkerman M, Evers SM: Cost-effectiveness of angiotensin-converting enzyme inhibitors for the prevention of diabetic nephropathy in the Netherlands - a Markov model. PLoS ONE 2011;6:e26139.

25 Gold MR, Siegel JE, Russell LB, Weinstein MC (eds.) Cost-effectiveness in Health and Medicine. New York: Oxford University Press, 1996.

26 Golan L, Birkmeyer JD, Welch HG: The cost-effectiveness of treating all patients with type 2 diabetes with angiotensin-converting enzyme inhibitors. Ann Intern Med 1999;131:660-667. 


\section{Kidney \\ Blood Pressure Research}

Adarkwah/Gandjour/Akkerman/Evers: ACE Inhibitors in Advanced Renal Disease

27 Rosen AB, Hamel MB, Weinstein MC, Cutler DM, Fendrick AM, Vijan S: Cost-effectiveness of full medicare coverage of angiotensin-converting enzyme inhibitors for beneficiaries with diabetes. Ann Intern Med 2005;143:89-99.

28 Terajima T, Yamagata S, Satoh N, Ueda S: Meta-analysis: effect of ACE-inhibitors on outcomes in patients with renal insufficiency. Pharm Ther 2003;28:98-112.

29 Mantel N, Haenszel W: Statistical aspects of the analysis of data from the retrospective analysis of disease. J Natl Cancer Inst 1959;22:719-748.

30 Kuntz KM, Weinstein MC: Modelling in economic evaluation. In: Drummond M, McGuire A, eds. Economic evaluation in health care: merging theory with practice. New York: Oxford University Press, 2005.

-31 Hemmelgarn BR, Manns BJ, Lloyd A, James MT, Klarenbach S, Quinn RR, Wiebe N, Tonelli M; Alberta Kidney Disease Network: Relation between kidney function, proteinuria, and adverse outcomes. JAMA 2010;303:423-429.

-32 Hoerger TJ, Wittenborn JS, Segel JE, Burrows NR, Imai K, Eggers P, Pavkov ME, Jordan R, Hailpern SM, Schoolwerth AC, Williams DE; Centers for Disease Control and Prevention CKD Initiative: A health policy model of CKD: 2. The cost-effectiveness of microalbuminuria screening. Am J Kidney Dis 2010;55:463-473.

-33 Fryback DG, Dasbach EJ, Klein R, Klein BE, Dorn N, Peterson K, Martin PA: The Beaver Dam Health Outcomes Study: initial catalog of health-state quality factors. Med Decis Making 1993;13:89-102.

34 Churchill DN, Torrance GW, Taylor DW, Barnes CC, Ludwin D, Shimizu A, Smith EK: Measurement of quality of life in end-stage renal disease: the time trade-off approach. Clin Invest Med 1987;10:14-20.

35 Arnesen T, Trommald M: Roughly right or precisely wrong? Systematic review of quality-of-life weights elicited with the time trade-off method. J Health Serv Res Policy 2004;9:43-50.

-36 Bleichrodt H, Johannesson M: Standard gamble, time trade-off and rating scale: experimental results on the ranking properties of QALYs. J Health Econ 1997;16:155-175.

-37 Dolan P, Gudex C, Kind P, Williams A: Valuing health states: a comparison of methods. J Health Econ 1995;15:209-231.

-38 Dale PL, Hutton J, Elgazzar H: Utility of health states in chronic kidney disease: a structured review of the literature. Curr Med Res Opin 2008;24:193-206.

39 Statline - Central Bureau for Statistics: Consumer prices; price index Available: http://statline.cbs.nl/StatWeb/ publication/?DM=SLEN\&PA=71311eng\&D1=4\&D2=0\&D3=12,25,38,51,64,77,90,103, 116,129,142,155, 168,181,194\&LA=EN\&HDR=T,G1\&STB=G2\&VW=T. Accessed 18 October 2011.

$\rightarrow 40 \mathrm{~K} / \mathrm{DOQI}$ clinical practice guidelines for chronic kidney disease: evaluation, classification, and stratification. Am J Kidney Dis 2002;39:S1-S266.

41 Royal College of Physicians: Chronic kidney disease - national clinical guideline for early identification and management in adults in primary and secondary care. London: Royal College of Physicians of London (2008).

42 College voor Zorgverzekeringen (CVZ). Dutch guidelines for pharmacoeconomic research; Diemen: CVZ. Available: http://www.ispor.org/peguidelines/source/PE_guidelines_english_Netherlands.pdf. Accessed 18 October 2011.

43 Farmacotherapeutisch kompas 2010, Medisch Farmaceutische Voorlichting, Uitgave van de Commissie Farmaceutische Hulp (CFH) van het College voor zorgverzekering (CVZ).

44 College Voor Zorgverzekeringen (CVZ). GIPeilingen 2009. Ontwikkelingen genees- en hulpmiddelengebruik. Available: http://www.cvz.nl/binaries/live/cvzinternet/hst_content/nl/ documenten/gipeilingen/gip2009.pdf. Accessed 18 October 2011.

45 Nederlandse Zorgautoriteit, Rapport Inkoopvordelen en praktijkkosten apotheekhoudenden 2009, 2010 en 2011, gevolgen voor flexibel tarief 2011, Nov. 2010, p. 52.

46 Nebel M: Costs of renal replacement therapies in Germany in 1999. Nieren- und Hochdruckkrankheiten 2002;3:85-92.

47 Oostenbrink JB, Bouwmans CAM, Koopmanschap MA, Rutten FFH: Handleiding voor kostenonderzoek. Methoden en standard kostprijzen voor economische evaluaties in de gezondheidszorg. Diemen: College voor zorgverzekeringen 2004.

48 Brouwer WB, Niessen LW, Postma MJ, Rutten FF: Need for differential discounting of costs and health effects in cost effectiveness analyses. BMJ 2005;331:446-448. 


\section{Kidney \\ Blood Pressure Research}

49 John JA, Whitaker D, Johnson DG: Statistical thinking in business (2nd ed.). Boca Raton, FL: Chapman \& Hall/CRC, 2006.

50 Palmer AJ, Valentine WJ, Chen R, Mehin N, Gabriel S, Bregman B, Rodby RA: A health economic analysis of screening and optimal treatment of nephropathy in patients with type 2 diabetes and hypertension in the USA. Nephrol Dial Transplant 2008;23:1216-1223.

-51 Whitworth JA; World Health Organization, International Society of Hypertension Writing Group. 2003 World Health Organization (WHO) / International Society of Hypertension (ISH) statement on management of hypertension. J Hypertens 2003;21:1983-1992.

52 Zidek W, Düsing R, Haller H, Middeke M, Paul M, Schmieder R, Schrader J; German Society of Hypertension: New recommendations of the German Hypertension League for the drug treatment of hypertension [in German]. Dtsch Med Wochenschr 2003;128:2468-2469.

53 Walma EP, Thomas S, Prins A, Grundmeyer HGLM, van der Laan JR, Wiersma TJ: NHG guideline hypertension, third revision (in Dutch). Huisarts Wet 2003;46:435-449.

54 Cardillo C, Mores N, Motolese M, Folli G: Effects of benazepril on stress testing blood pressure in essential hypertension. Am J Cardiol 1994;73:368-373.

55 Yusuf S, Sleight P, Pogue J, Bosch J, Davies R, Dagenais G: Effects of an angiotensin-converting-enzyme inhibitor, ramipril,on cardiovascular events in high-risk patients. N Engl J Med 2000;342:145-153.

56 Wilmer WA, Rovin BH, Hebert CJ, Rao SV, Kumor K, Hebert LA: Management of glomerular proteinuria: a commentary. J Am Soc Nephrol 2003;14:3217-3232.

57 Hebert LA, Wilmer WA, Falkenhain ME, Ladson-Wofford SE, Nahman NS Jr, Rovin BH: Renoprotection: one or many therapies? Kidney Int 2001;59:1211-1226.

-58 Praga M: Slowing the progression of renal failure. Kidney Int 2002;80:S18-S22.

59 Nakao N, Yoshimura A, Morita H, Takada M, Kayano T, Ideura T: Combination treatment of angiotensinII receptor blocker and angiotensin-converting-enzyme inhibitor in non-diabetic renal disease (COOPERATE): a randomised controlled trial. Lancet 2003;361:117-124.

60 Perna A, Ruggenenti P, Testa A, Spoto B, Benini R, Misefari V, Remuzzi G, Zoccali C: ACE genotype and ACE inhibitors induced renoprotection in chronic proteinuric nephropathies. Kidney Int 2000;57:274-281.

61 Statline - Central Bureau for Statistics: Overlevingstafels (2010) Available: http://statline.cbs.nl/ StatWeb/publication/?DM=SLNL\&PA=37360NED\&D1=0\&D2=a\&D3=a\&D4=l\&HDR=G1,T\&STB=G2 G3\&CHARTTYPE=1\&VW=T Accessed 18 October 2011. 